ДОСЛІДЖЕННЯ ЕМОЦІЙНОГО ІНТЕЛЕКТУ СТУДЕНТІВ-ГАНДБОЛІСТІВ (НА ПРИКЛАДІ ЮНАКІВ І ДІВЧАТ)

\title{
STUDY OF EMOTIONAL INTELLIGENCE OF STUDENTS-HANDBALL PLAYERS (ON THE EXAMPLE OF BOYS AND GIRLS)
}

У статmі розглянуто сучасне значення емоційного інтелекту в студентів, які займаються гандболом. Мета дослідження: вивчення психологічних особливостей емоційного інтелекту студентів-спортсменів, які спеціалізуються в гандболі, та осіб, які не займаються спортом. Для вирішення поставлених завдань використані теоретичні (аналіз, порівняння, узагальнення), організаційні (порівняльний, комплексний методи), емпіричні методи, а також методи обробки даних та інтерпретаційні методи: психодіагностичні методики емоційного інтелекту H. Холла; дослідження особистісної та реактивної тривожності Ч. Спілбергера. Наведено результати дослідження емоційного інтелекту та його складників спортсменів-гандболістів, надано їх рівневу характеристику. Дослідження проводилося на базі Національного технічного університету «Дніпровська політехніка», проходили у орормі опитування. у дослідженні взяли участь студенти-гандболісти віком 17-22 роки (40 спортсменів, юнаки та дівчата). Розряд спортсменів II дорослий - КМС. Достовірні відмінності ( $p<0,05 ; 0,001)$ виявлені за компонентами: управління власними емоціями, самомотивація, розпізнавання емоцій інших людей, тоді як за шкалами емоційної обізнаності й емпатії достовірної різниці немає. У ході аналізу результатів дослідження виявлено достовірний $(p<0,05)$ зворот ний кореляційний зв'язок між показниками емоційного інтелекту й рівнем особистісної та ситуативної тривожності в осіб 17-22 років. У дівчат-гандболісток виявлено зворотні достовірні взаємозв'язки між показником емоційного вигоряння «емочійне/фрізичне виснаження» та самомотивацією $(r=0,46, p<0,01)$, керуванням своїми емоціями ( $r=0,64, p<0,01) ;$ показником емочійного вигоряння «знецінення досягнень» і самомотивацією $(r=0,52, p<0,01)$, керуванням своїми емоціями ( $r=0,59, p<0,01)$; сумарним значенням емоційного вигоряння й керування своїми емоціями $(r=0,60, p<0,01)$. Проведене дослідження орієнтоване на вирішення проблеми розвитку емочійного інтелекту спортсменів на різних етапах підготовки, що сприятиме підвищенню рівня ефрективності психологічної підготовки студентів-гандболістів.

Ключові слова: емоційний інтелект, гандбол, студентський спорт, гендерний аспект.

The article considers the modern importance of emotional intelligence in students who play handball. The purpose of the study: to study the psychological characteristics of the emotional intelligence of students-athletes who specialize in handball and people who do not play sports. Theoretical (analysis, comparison, generalization), organizational (comparative, complex methods), empirical methods, as well as data processing methods and interpretive methods were used to solve the tasks: psychodiagnostic methods of N. Hall's emotional intelligence; study of personal and reactive anxiety by Charles Spielberger. The results of the study of emotional intelligence and its components of handball athletes are given, their level characteristics are given. The study was conducted on the basis of the National Technical University "Dnieper Polytechnic", which took the form of a survey. The study involved handball students aged 17-22 (40 athletes, boys and girls). Category of athletes - II adult - CMS. Significant differences $(p<0,05 ; 0,001)$ were found by components: self-emotion management, self-motivation, recognition of other people's emotions, while on the scales of emotional awareness and empathy there is no significant difference. The analysis of the results of our study revealed a significant $(p<0,05)$ inverse correlation between the indicators of emotional intelligence and the level of personal and situational anxiety in people 17-22 years. In girls-handball players, inverse reliable relationships were found between the rate of emotional burnout "emotional/physical exhaustion" and self-motivation ( $r=0,46, p<0,01)$, managing their emotions $(r=0,64, p<0,01)$; indicator of emotional burnout "depreciation of achievements" and self-motivation ( $r=0,52, p<0,01)$, self-management $(r=0,59, p<0,01)$; the total value of emotional burnout and control of their emotions $(r=0,60, p<0,01)$. The study is focused on solving the problem of developing the emotional intelligence of athletes at different stages of training, which will increase the effectiveness of psychological training of handball students.

Key words: emotional intelligence, handball, student sports, gender aspect.
Національний технічний університет

«Дніпровська політехніка»
Проблема вивчення емоційного інтелекту набирає все більшої популярності в сучасному світі. Як відомо, емоційний інтелект є важливою стороною когнітивних здібностей людини $[2$, с. $7 ; 4$, с. 89].

Сьогодні в низці літературних джерел представлено різні підходи до інтерпретації поняття емоційного інтелекту, розроблено різноманітні моделі та концепції, розробляються нові методики діагностики емоційного інтелекту $[1$, с. $62 ; 6$, с. $46 ; 9 ; 11$, с. 60$]$.
Наприклад, сучасна інтерпретація емоційного інтелекту зводиться до таких положень: П. Селовей, Дж. Мейєр розглядають емоційний інтелект «як здатність сприймати й розуміти прояви особистості, що виражаються в емоціях, керувати емоціями на основі інтелектуальних процесів» [13, с. 197]. Д. Гоулман розуміє як «здатність усвідомлювати свої емоції та емоції інших людей, щоб мотивувати себе й інших і добре управляти емоціями наодинці з собою та при взаємодії з іншими» [7, с. 201; 8, с. 156]. 
Також розглянуто здатність розуміти відносини особистості, що репрезентуються в емоціях, і керувати емоційною сферою на основі інтелектуального аналізу й синтезу (P. Salovey, J.D. Mayer, 2004 [13, с. 205]; сукупність емоційних, особистих і соціальних здібностей, які впливають на загальну здатність будь-кого ефективно справлятися з вимогами й тиском навколишнього середовища (Р. Бар-Он, 2000) [11, c. 61].

Наприклад, Р.О. Агавелян та Н.В. Ілясова в роботі відображають відмінності в рівні розвитку емоційного інтелекту в представників різних видів спорту (як командних, так й індивідуальних) [9, с. 4].

Як зазначають деякі автори, одним зі способів вирішення цього питання $€$ підвищення рівня психологічної підготовки, а саме розвиток емоційного інтелекту спортсменів різної кваліфікації, оскільки відсутність контролю над емоційним станом перешкоджає ефективному виконанню техніко-тактичних дій при значних фізичних навантаженнях у змаганнях різного рівня [3, с. 107; 10].

За даними деяких авторів, одним зі способів вирішення цього питання $€$ підвищення рівня психологічної підготовки, а саме розвиток емоційного інтелекту спортсменів різної кваліфікації, оскільки відсутність контролю над емоційним станом перешкоджає ефективному виконанню техніко-тактичних дій при значних фізичних навантаженнях у змаганнях різного рівня.

На розуміння власних емоцій та емоцій інших людей впливає рівень розвитку емоційного інтелекту, що він вищий, то краще виражена здатність до розуміння. Емоційний інтелект, на відміну від конкретного й абстрактного, які показують закономірності зовнішнього світу, виражає внутрішній світ і його зв'язок із поведінкою індивіда та взаємодії з реальністю [5, с. 145].

Проаналізувавши результати дослідження вітчизняних, зарубіжних учених із вивчення емоційного інтелекту в спортивній діяльності, ми виявили, що це питання потребує подальшого вивчення в напрямі спортсменів-гандболістів.

Мета дослідження - вивчити психологічні особливості емоційного інтелекту студентів-спортсменів, які спеціалізуються в гандболі й осіб, які не займаються спортом.

Для реалізації поставленої мети ми виділили необхідні завдання:

1. Аналіз і вивчення науково-методичної літератури, що розкриває проблематику досліджуваного питання.

2. Підбір психодіагностичного інструментаpiю.

3. Проведення психодіагностичного обстеження емоційного інтелекту студентів-спортсменів обох статей, які займаються гандболом.
4. Формулювання висновків про особливості емоційного інтелекту у студентів-гандболістів.

Методи дослідження. Для вирішення поставлених завдань використано теоретичні (аналіз, порівняння, узагальнення), організаційні (порівняльний, комплексний методи), емпіричні методи, а також методи обробки даних та інтерпретаційні методи: психодіагностичні методики емоційного інтелекту Н. Холла; дослідження особистісної та реактивної тривожності Ч. Спілбергера.

У дослідженні взяли участь студенти-гандболісти віком 17-22 роки, розряд II - КМС. Загалом у дослідженні взяли участь 40 спортсменів (юнаки й дівчата).

Дослідження проводилося на базі Національного технічного університету «Дніпровська політехніка», які проходили у формі опитування. Матеріал був відкритими питаннями з необмеженим обсягом відповіді досліджуваного, а також стандартизовані методики з формалізованими відповідями. Кожна методика оцінювалася в балах, які потім підсумовувалися.

Емоційний інтелект трактується фахівцями як здатність до розуміння й управління власними емоціями та емоціями інших людей. Найбільш визнана в науці модель емоційного інтелекту складається 3 таких складників: усвідомлення власних емоцій і вміння ними керувати, розпізнавання емоцій інших людей і вміння налагоджувати й підтримувати стосунки з людьми [12, с. 10].

Порівняння показників розвитку емоційного інтелекту студентів-спортсменів 17-22 років і їхніх однолітків, які не займалися спортом, виявило достовірні ( $<<0,05 ; 0,001)$ відмінності. За результатами наших досліджень, заняття спортом як вид діяльності істотно впливає на рівень розвитку емоційного інтелекту в студентів-гандболістів.

Достовірні відмінності $(p<0,05 ; 0,001)$ виявлені за компонентами: управління власними емоціями, самомотивація, розпізнавання емоцій інших людей, тоді як за шкалами емоційної обізнаності й емпатії достовірної різниці немає $(p \geq 0,05)$.

Особистісна та ситуативна тривожність, як відомо, мають досить складну взаємодію. 3 одного боку, особистісна тривожність певною мірою визначає той вид діяльності, який вибирає собі людина, з іншого - чим частіше специфіка діяльності для успішного вирішення завдань вимагає розвитку вміння регулювати стан тривожності, тим нижчі показники ситуативної тривожності у відповідь на ситуацію, характерну для цього виду діяльності.

3 іншого боку, досвід успішного контролю ситуативної тривожності особистості зазвичай переноситься на інші життєві ситуації. 
Уважаємо за потрібне відзначити, що в дослідженні ми не констатуємо зниження або підвищення рівня тривожності, а акцентуємо увагу на досягненні оптимального її рівня для кожної особи, яка б сприяла успішній діяльності.

Багато досліджень емоційного інтелекту останніх років присвячено його впливу на ефективність виконання професійної діяльності [2, с. 87; 7, с. 203]. Виявлено, що ефективність професійної діяльності залежить не тільки від знань спеціаліста певної сфери діяльності, а й від його особистісних особливостей - стійкої системи стосунків до власного внутрішнього та навколишнього світу.

Варто зазначити, що високий рівень розвитку емоційного інтелекту дає змогу регулювати свою поведінку, утілити поставлену мету, реалізувати намічений результат.

Для цього при моделюванні діяльності змагання використовуються максимально можливі труднощі, які викликають стан психічного напруження, мобілізацію сил і можливостей організму спортсменів.

У гандболі проводяться багатоетапні цілорічні змагання, що може призводити не тільки до зростання психічних навантажень, а й до виникнення емоційного вигоряння. Ми припускаємо, що емоційний інтелект допомагає спортсменам як конструктивно взаємодіяти з оточуючими, так і розрізняти й інтерпретувати власні емоції, контролювати їх і керувати ними, що, безумовно, сприяє запобіганню психічним навантаженням, зокрема перешкоджає й виникненню емоційного вигоряння.

Моделювання діяльності змагань $є$ потужним засобом підвищення ефективності підготовки спортсменів до діяльності змагань і найчастіше спрямоване на вирішення проблеми емоційної стійкості спортсменів.

Щодо спортивної діяльності поліпшення рівня розвитку емоційного інтелекту сприятиме позитивному впливу на психологічну підготовку в цілому, а саме на емоційно-вольову регуляцію, емоційну стійкість, а також сприятиме запобіганню вигорянню емоційної сфери спортсменів, оскільки емоції визначають поведінку, містять сигнальну мотивацію реакції у відповідь на певну ситуацію [12, с. 289].
У цьому всі аспекти підготовки спортсменів можна охарактеризувати активністю емоційного інтелекту особистості, що забезпечує швидше й ефективне освоєння спортивних вправ.

Емоційний інтелект оцінювався за допомогою методики Н. Холла, призначеної для виявлення здатності розуміти відносини особистості, що репрезентуються в емоціях, та управління емоційною сферою на основі прийняття рішень. Він містить 5 шкал: емоційну поінформованість, керування своїми емоціями, самомотивацію, емпатію, розпізнавання емоцій інших людей.

Отримані результати на прикладі юнаків наведено в таблиці 1.

Спортсмени з високим рівнем розвитку емоційного інтелекту мають виражені здібності до розуміння власних емоцій та емоцій інших людей, до управління емоційною сферою, що зумовлює більш високу адаптивність та ефективність у спілкуванні. На відміну від абстрактного й конкретного інтелекту, що відображають закономірності зовнішнього світу, емоційний інтелект відображає внутрішній світ і його зв'язки з поведінкою особистості та взаємодією з реальністю.

Результати кореляційного дослідження дають змогу говорити про значний зворотний взаємозв'язок між показником емоційного вигоряння “зменшення почуття досягнення» та розпізнаванням емоцій у чоловічій вибірці $(r=0,52, p<0,01)$. Отже, чим краще респонденти розпізнають емоції оточуючих і свої, тим нижча ймовірність виникнення проявів емоційного вигоряння.

У дівчат-гандболісток виявлено зворотні достовірні взаємозв'язки між показником емоційного вигоряння «емоційне/фізичне виснаження» та самомотивацією ( $r=0,46, p<0,01)$, керуванням своїми емоціями $(r=0,64, p<0,01)$; показником емоційного вигоряння «знецінення досягнень» і самомотивацією $(r=0,52, p<0,01)$, керуванням своїми емоціями ( $r=0,59, p<0,01)$; сумарним значенням емоційного вигоряння та керуванням своїми емоціями $(r=0,60, p<0,01)$.

Серед випробуваних жіночої команди з гандболу виявлено більшу кількість взаємозв'язків між показниками вигоряння й емоційного

Показники емоційного інтелекту студентів-гандболістів і неспортсменів (юнаки)

Таблиця 1

\begin{tabular}{|l|c|c|c|c|c|c|}
\hline \multirow{2}{*}{ Показники емоційного інтелекту } & \multicolumn{2}{|c|}{ Неспортсмени (n=18), \% } & \multicolumn{2}{c|}{ Гандболісти-юнаки (n=22), \% } \\
\cline { 2 - 7 } & високий & середній & низький & високий & середній & низький \\
\hline 1. Емоційна поінформованість & 0 & 28 & 72 & 12,5 & 25 & 62,5 \\
\hline 2. Управління своїми емоціями & 0 & 0 & 100 & 0 & 8,3 & 91,7 \\
\hline 3. Самомотивація & 0 & 54,2 & 45,8 & 16,7 & 45,4 & 37,8 \\
\hline 4. Емпатія & 0 & 27 & 73 & 0 & 41,7 & 58,3 \\
\hline 5. Розпізнавання емоцій інших людей & 21 & 35,2 & 62,5 & 0 & 37,7 & 62,7 \\
\hline $\begin{array}{l}\text { 6. Інтегративний показник рівня } \\
\text { емоційного інтелекту }\end{array}$ & 0 & 12,6 & 87,5 & 0 & 29,4 & 70,6 \\
\hline
\end{tabular}


інтелекту $(r=0,58-0,82, p<0,001)$, ніж у чоловічій, що говорить про більший вплив емоцій на емоційну компетентність і розвиток вигоряння в респондентів жіночої статі.

Висновки 3 проведеного дослідження. Згідно 3 результатами проведеного дослідження, емоційний інтелект і його складники в більшості спортсменів різної кваліфікації перебувають на низькому рівні. Це вказує на недостатній рівень розпізнавання своїх емоцій та емоцій інших людей, а також контролювання їх. Ці вміння відіграють одну з ключових ролей для емоційної стійкості спортсменів у змагальній діяльності, що, своєю чергою, впливає на результат у змаганнях.

Проведене дослідження вказує на необхідність проведення заходів щодо розвитку емоційного інтелекту та його складників у спортсменів різної кваліфікації, оскільки наявність досвіду тренувальної та змагальної діяльності не чинить прямого впливу на наявність емоційного інтелекту спортсменів. Таким чином, існує необхідність подальшого вивчення проблеми емоційного інтелекту, його складників і способів його розвитку.

Емоційний інтелект включає здатність до диференціації, розуміння емоцій і керування ними, що дуже важливо для досягнення оптимального рівня тривожності особистості. У ході аналізу результатів дослідження виявлено достовірний $(p<0,05)$ зворотний кореляційний зв'язок між показниками емоційного інтелекту й рівнем особистісної та ситуативної тривожності в осіб 17-22 років.

Результати дослідження вказують на значущість для студентів-спортсменів, які займаються гандболом, емоційної компетентності як чинника успішного подолання емоційних навантажень.

\section{ЛІТЕРАТУРА:}

1. Белоконь В.О., Горская Г.Б. Роль эмоционального и социального интеллекта в поддержании психической устойчивости субъектов командной деятельности. Вестник ТвГУ. Серия «Педагогика и психология». 2019. № 4 (49). С. 62-72.

2. Бобкова Н.Г. Эмоциональный интеллект как ключевая компетенция современного менеджера. Бизнес-образование в экономике знаний. 2016. № 2 (4). C. 7-11.
3. Босенко Ю.М., Берилова Е.И. Личностные и когнитивные фракторы стрессоустойчивости спортсменов высокого класса. Вестник Костромского государственного университета им. Н.А. Некрасова. Серия «Педагогика. Психология. Социальная работа. Ювенология. Социокинетика». 2015. Т. 21. № 2. C. 106-110.

4. Бредберри Т., Гривз Дж. Эмоциональный интеллект: самое важное. Москва : АСТ Москва, 2008. С. 89.

5. Берилова Е.И. Эмоциональный интеллект как фрактор стрессоустойчивости у спортсменов разного пола. Материалы науч. и науч.-метод. конфр. профр.-препод. состава Кубан. гос. ун- та физ. культуры, спорта и туризма. 2015. № 2. С. 144-145.

6. Гасанпур М.К. Сравнение эмоционального интеллекта у студентов-спортсменов и неспортсменов С точки зрения его роли в управлении индивидуальными и социальными эмоциями. Вектор науки ТГУ. Серія «Педагогика, психология». 2014. № 1 (16). C. 46-48.

7. Гоулман Д. Эмоциональный интеллект: Ценное практическое руководство по развитию и совершенствованию эмоций человека / пер. с англ. А.П. Исаевой. Москва : Хранитель, 2008. C. 201-205.

8. Гоулман Д., Бояцис Р., Макки Є. Эмоциональное лидерство: Искусство управления людьми на основе эмоционального интеллекта / пер. с англ. Москва : Альпина Бизнес Букс, 2005. С. 156.

9. Илясова Н.В.,Агавелян Р.О. Особенности эмоционального интеллекта спортсменов индивидуальных и командных видов спорта. Проблемы науки. 2014. № 11 (29). URL: https://cyberleninka.ru/article/n/ osobennosti-emotsionalnogo-intellekta-sportsmenovindividualnyh-i-komandnyh-vidov-sporta (дата обращения: 13.12.2019).

10. Малкин В.Р., Рогалева Л.Н., Бредихина Я.А. Изучение влияния спорта на эмоциональный интеллект студентов-спортсменов. Междунар. студ. науч. вестн. 2017. № 4-8. URL: http://www.eduherald.ru/ru/ article/view? id=17659 (дата обращения: 05.02.2020).

11. Петровская Т. Эмоциональный интеллект и соревновательная тревожность спортсменов. Наука в олимпийском спорте. 2014. № 4. С. 60-63.

12. Malinauskas R. Peculiarities of emotional states of sportsmen in cyclic sports. International journal of sport psychology. 2003. № 34 (4). P. 289-298.

13. Mayer J.D., Salovey P.D., Caruso R. Emotion intelligence: theory, findings, and implication. Psychol. Inq. 2004. Vol. 15. № 3. P. 197-215. 